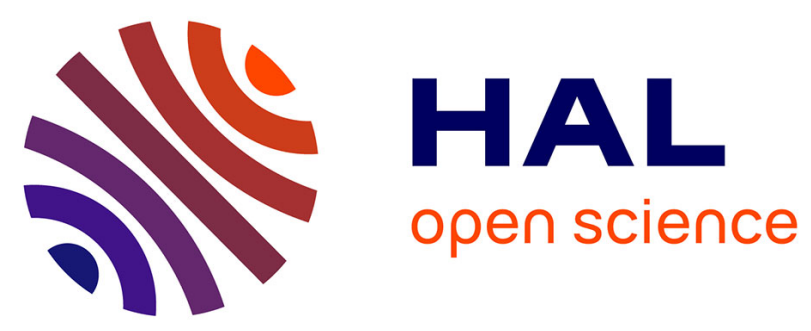

\title{
Evaluation of a commercial multiplex PCR test (SeptiFast) in the etiological diagnosis of community-onset bloodstream infections
}

P. Josefson, K. Strålin, A. Ohlin, T. Ennefors, B. Dragsten, L. Andersson, H. Fredlund, P. Mölling, P. Olcén

\section{To cite this version:}

P. Josefson, K. Strålin, A. Ohlin, T. Ennefors, B. Dragsten, et al.. Evaluation of a commercial multiplex PCR test (SeptiFast) in the etiological diagnosis of community-onset bloodstream infections. European Journal of Clinical Microbiology and Infectious Diseases, 2011, 30 (9), pp.1127-1134. 10.1007/s10096-011-1201-6 . hal-00676224

\section{HAL Id: hal-00676224 \\ https://hal.science/hal-00676224}

Submitted on 4 Mar 2012

HAL is a multi-disciplinary open access archive for the deposit and dissemination of scientific research documents, whether they are published or not. The documents may come from teaching and research institutions in France or abroad, or from public or private research centers.
L'archive ouverte pluridisciplinaire HAL, est destinée au dépôt et à la diffusion de documents scientifiques de niveau recherche, publiés ou non, émanant des établissements d'enseignement et de recherche français ou étrangers, des laboratoires publics ou privés. 
2 Evaluation of a commercial multiplex PCR (SeptiFast) in the aetiological

7 Per Josefson ${ }^{1 *}$, Kristoffer Strålin ${ }^{1}$, Andreas Ohlin ${ }^{2}$, Theresa Ennefors ${ }^{3}$, Birgitta Dragsten ${ }^{3}$, Linda Andersson ${ }^{3}$, Hans Fredlund $^{3}$, Paula Mölling ${ }^{3}$, Per Olcén ${ }^{3}$

* Corresponding author. Mailing address: Department of Infectious Diseases, Örebro University Hospital, S-701 85 Örebro, Sweden. Phone: + 46196021488. 


\section{Abstract}

Purpose: The commercial PCR test SeptiFast is designed to identify DNA of individual

bacterial and fungal pathogens in whole blood. We aimed to evaluate the usefulness of the test for detection of community onset bloodstream infections.

Methods: We prospectively included adult patients who were subjected to blood culture (BC) at an infectious diseases department. For the evaluation one BC/PCR set (two BC bottles and one PCR tube) per patient was used. When several sets were obtained and analyzed the first set with any positive result was evaluated.

Results: Among 1093 consecutively included patients, BC was positive in 138 and PCR was positive in 107. Fifty positive PCR results were supported by BC in the same BC/PCR set, 10 were supported by other cultures, and additionally, 10 were supported by the clinical presentation. Compared with BC, PCR showed specificities and negative predictive values of $>97 \%$ for all detectable pathogens. The following sensitivities and positive predictive values (PPVs) were noted: Staphylococcus aureus, $67 \%$ and 43\%; Streptococcus pneumoniae, $12 \%$ and 67\%; other Streptococcus species, $43 \%$ and 77\%; Escherichia coli, 53\% and 56\%; and

Klebsiella species, $43 \%$ and $23 \%$. If support from other cultures and the clinical presentation were included in the reference standard, the PPVs for detection of these bacteria were $57 \%$, $100 \%, 92 \%, 75 \%$ and $69 \%$, respectively.

Conclusions: Although the specificities were high, the low sensitivities and suboptimal PPVs noted in the present study discourage routine use of the test in its present form for detection of community onset bloodstream infections.

Keywords: PCR, Sepsis, Bacteraemia, Diagnostic test, Evaluation 


\section{Introduction}

Bloodstream infections are important causes of morbidity and mortality in patients worldwide. Rapid etiological diagnosis and early administration of adequate antimicrobial therapy soon after a critically ill patient's arrival at the hospital are important for a successful outcome $[1,2]$. Inadequate antimicrobial treatment has been reported to be associated with increased mortality $[3,4]$.

Blood culture (BC) is at present considered the diagnostic gold standard for bloodstream infections, with high specificity in species identification. However slow-growing and fastidious organisms can delay diagnosis and prior antimicrobial treatment reduces the sensitivity of the BC method.

New non-culture-based techniques are consequently being developed for the diagnosis of septicaemia/bacteraemia $[5,6,7]$. One of the approaches for potentially faster pathogen identification is to use target-amplification methods, including molecular amplification with polymerase chain reaction (PCR). General methods that use genes for ribosomal RNA can create problems with contaminating bacteria, causing impaired analytical specificity and sensitivity [8]. A new commercially available multiplex PCR (SeptiFast, Roche Diagnostics $\mathrm{GmbH}$ ) with the potential to identify 19 different bacterial species and 6 fungal species in whole blood has been developed [9]. The aim of the present prospective, diagnostic study was to evaluate this new PCR by comparing it with $\mathrm{BC}$ in a large, consecutive, non-selective group of adult patients seen at a department of infectious diseases in southern Sweden. We estimated that about 1000 different patients would be subjected to BC during one year, with about 100 positive BCs. 


\section{Materials and methods}

77 Patients

78

79 The Department of Infectious Diseases, Örebro University Hospital, Sweden, provides service for a population of 275.000 inhabitants in the county of Örebro and has a ward with 30 beds

81 for adults and an outpatient clinic.

82 In the present prospective study we enrolled all adult patients who were subjected to $\mathrm{BC}$ at the

83 department and gave their informed consent during one full year from October 2007 to

84 September 2008. Excluded were patients with HIV and with hepatitis B and C infections for 85 local laboratory safety reasons.

86

\section{SeptiFast method}

Whole blood was collected in sterile EDTA tubes (BD Vacutainer ${ }^{\mathrm{TM}} \mathrm{K} 3 \mathrm{E} 15 \%$, Becton,

90 Dickinson and Company, Plymouth, UK) through the same venepuncture as the blood

91 samples for BC were taken. The whole blood was then stored for a maximum of 4 hours at

92 room temperature, or up to three days at $+4^{\circ} \mathrm{C}$, or 3 months at $-70^{\circ} \mathrm{C}$ prior to DNA

93 preparation. The DNA preparations were handled identically.

94 The internal transcribed spacer region (ITS) is used in the SeptiFast assay (Roche Diagnostics

$95 \mathrm{GmbH}$, Mannheim, Germany) as the target to specifically distinguish 25 different bacterial

96 and fungal pathogens (see Table 1). As detection format, hybridization probes are used.

97 DNA was extracted from $1.5 \mathrm{ml}$ of an EDTA whole-blood sample. The protocol of the

98 manufacturer was followed, including a first step of mechanical lysis using the SeptiFast Lys

99 Kit MGrade and the MagNALyser®. The DNA was prepared manually using the SeptiFast 
100 Prep Kit MGrade (Roche Diagnostics GmbH). In the extraction step an internal control (IC)

101 was added to each sample. The IC is a mixture of synthetic double-stranded DNA molecules

102 with primer binding sites identical to those of the target sequences, differing in their probe

103 binding sites. A negative control supplied by the manufacturer was included in each

104 extraction series and the reagent controls were used as positive control of the PCR reactions.

105 Gram-positive bacteria, Gram-negative bacteria, and fungi were amplified individually in

106 three different mixes. The real-time PCR was performed in a LightCycler 2.0 instrument

107 (Roche Diagnostics GmbH). The emitted fluorescence was measured in one of the four

108 different detection channels $(610,640,670$, and $705 \mathrm{~nm})$. Analysis of the melting curves were

109 performed to strengthen the specificity of the products. The PCR amplicons from the

110 specimens and ICs were analyzed by a pathogen identification software (SIS; SeptiFast

111 Identification Software, Roche Diagnostics $\mathrm{GmbH})$. The software automatically calculated

112 the melting point $(\mathrm{Tm})$ value and the corresponding peak height. For the Gram-positive assay

113 the analysis was based on melting peaks ( $T \mathrm{~m}$ and peak height) and amplification curve

114 crossing point $(\mathrm{Cp})$ values. The assays for Gram-negative and Fungi were solely based on

115 melting peaks and $\mathrm{Cp}$ values were not considered. To reduce false positive results by assumed

116 contaminants the software also includes Cp cut-off values, ex for CoNS and Streptococcus

117 species this cut-off value is at 20 cycles. The assay was flagged as "Invalid" if the software

118 could identify neither a specimen nor the IC. The turn-around time was $6 \mathrm{~h}$. The results of the

119 PCR assays were unknown to the clinicians until the closure of the study.

121 Blood culture

122

123 Blood culture was performed with the Bactec system (Becton, Dickinson and Company, 124 Sparks, MD, USA) as a standard procedure in patients with suspected disseminated bacterial 
and/or fungal infection.

126 For each BC a volume of 8-10 $\mathrm{ml}$ of venous blood was inoculated in one Bactec Plus

127 Aerobic/F bottle and the same volume in one Bactec Plus Anaerobic/F bottle.

128 After transport at room temperature the bottles were placed in a Bactec 9240 incubator, with

129 monitoring for $\mathrm{pH}$ changes every 10 minutes for 6 days.

130 All signaling bottles were opened and an aliquot was taken for microscopy after Gram

131 staining, culture on solid media, and further analyses for species designation according to the

132 good laboratory practice of our accredited clinical diagnostic microbiological laboratory.

\section{Other cultures}

135

136 Cultures from normally sterile sites and from urine, wounds and respiratory secretions were

137 performed according to standard microbiological procedures [10]. The choices of performing

138 such cultures were based on the clinical judgement of the clinicians.

140 Clinical data

141

142 At inclusion clinical data were collected, including information on whether antibiotics had

143 been taken within 3 days prior to BC. A retrospective chart review was performed by two

144 specialists of infectious diseases (P.J., K.S.).

145

146 Analysis

147

148 The SeptiFast results were compared with the results of $\mathrm{BC}$ and other microbiological data.

149 Although we routinely collected paired BC, we included for evaluation only one BC/PCR set 
150 (two BC bottles and one PCR tube taken at the same time) per patient. If it was not negative

151 in these analyses, the first BC/PCR set providing any positive result was included.

152

\section{Definitions}

154

155 A positive PCR result was considered to be fully supported when an identical microorganism

156 was isolated in the $\mathrm{BC}$ of the same BC/PCR set. Other microbiological support for a positive

157 PCR was defined as other positive BCs, cultures from normally sterile sites and from

158 bronchial secretion, and pure culture in urine and wounds. Wound culture with mixed flora

159 including Staphylococcus aureus and $\beta$-haemolytic streptococci was also regarded as other

160 microbiological support.

161

162 In the cases of a positive PCR result without any microbiological support, we made a

163 retrospective attempt to find clinical support for the positive PCR result. We considered a

164 PCR result to have clinical support if the species identified by PCR generally was considered

165 to be a common pathogen of the patient's type of infection, and if no microbiological support

166 for any other pathogen was identified.

167

168 The regional ethical committee approved the study.

169

170 Results

171

172 During the study period the total number of patients subjected to $\mathrm{BC}$ at the department were

1731540 and a positive BC was found in 208 of them.

174 
175 Altogether 1093 patients were included in the present study, 486 females (44\%) and 607

176 males (56\%). All these patients had results from at least one BC/PCR set. Of the included

177 patients the median age was 67 years (range 14-98 years). ICU care were received by 36

178 patients. The crude mortality rate within 30 days was $45 / 1093(4 \%)$.

179

180 Blood culture and/or PCR was positive for any pathogen in 197 patients (18\%) and in 896

181 patients the BC/PCR sets were negative. A positive $\mathrm{BC}$ was found in 138 of the patients and

182107 patients had positive SeptiFast results.

183

184 The results regarding the pathogens detected by BC and/or PCR for species included in the

185 PCR test menu are summarized in Table 2 . The most commonly detected pathogens were

186 Coagulase-negative Staphylococcus (CoNS), Staphylococcus aureus, Streptococcus

187 pneumoniae, other Streptococcus species, Escherichia coli, and Klebsiella species. Results

188 from patients who received antibiotic treatment within 3 days prior to $\mathrm{BC}$ are shown for each

189 pathogen. In total there were 50 results that were positive both in PCR and BC, 64 results that

190 were positive only with PCR and 86 results that were positive only with BC among the

191 pathogens on the PCR test menu.

192

193 Concerning CoNS, 10 were positive only with PCR, 30 were positive only with BC and only

1941 was positive with both PCR and BC. It may also be noted that for S. pneumoniae 14 were

195 positive only with BC, 1 was positive only with PCR during antibiotic treatment and 2 were

196 positive with both PCR and BC. Regarding other Streptococcus species, 13 were positive only

197 with BC, among which 4 were positive for Str. pyogenes and 7 were positive for other $\beta$ -

198 haemolytic streptococci (one of which with invalid result in PCR). Three results were positive

199 for other Streptococcus species by PCR only. PCR and BC were positive for 10 results, and of 
these 2 were positive for Str. pyogenes and 4 were positive for other $\beta$-haemolytic streptococci according to BC.

202

With BC 10 different isolated pathogens that are not included in the PCR test menu, were also found in 10 patients. They were Aerococcus viridans, Arcanobacterium haemolyticum, Pseudomonas fluorescens, Shigella flexneri, Bacteroides species, Citrobacter species,

Corynebacterium species, Fusobacterium species, Porphyromonas species, and Salmonella species.

Polymicrobial results were obtained in 12 patients, and are shown in Table 3.

211 In Table 4 the PCR-positive results are compared with results of BC and other cultures in an 212 attempt to find other support for a positive PCR result. In the cases of positive PCR without 213 microbiological support, clinical support is presented.

214

215 For S. aureus other microbiological support was in one case another positive BC and a 216 positive joint culture, in one case another positive BC and culture from cerebrospinal fluid, 217 and in one case a positive culture from a renal cortical cyst. For Streptococcus species other 218 microbiological support consisted of wound culture, including $\beta$-haemolytic streptococci in 2 219 cases. Other microbiological support was other positive BC in 2 cases for E. coli, and other positive $\mathrm{BC}$ in 2 cases and in one case pure culture in urine for Klebsiella.

222 Positive PCR results without any microbiological or clinical support were obtained for 223 example with CoNS in 10 cases, S. aureus in 10 cases, E. coli in 8 cases and Pseudomonas 224 aeruginosa in 4 cases. 
226 In total there were 114 positive PCR results from 107 patients, and 50 of them were fully

227 supported by BC in the same BC/PCR set, and 10 by other cultures; additionally 10 results

228 were supported by the clinical presentation. In 44 cases no microbiological or clinical support 229 was found.

230

231 Compared with BC, the SeptiFast test showed specificities of over 98\% and negative

232 predictive values of over $97 \%$ for all detectable pathogens. In Table 5 sensitivities and

233 positive predictive values (PPVs) are presented for major bacterial pathogens. PPVs are also

234 shown with a combined reference standard including other microbiological support and

235 clinical support.

236

237 Discussion

238

239 The theoretical advantages of a non-culture diagnostic method such as PCR for bacteraemia,

240 as compared to normal BC, include a substantially shorter time for reporting the test result

241 (both positive and negative) and detection of DNA in the blood without live microorganisms

242 after for example antibiotic treatment.

243

244 The development of PCR tests for diagnosis of bacteraemia is hence of great clinical interest

245 and assays have been designed and tried without a major breakthrough so far. The problems

246 include the large number of bacterial species (and fungi) that are clinically relevant, the

247 sometimes minute amounts of microbial DNA as compared to the huge amount of human

248 DNA, and contaminants in connection with the blood sampling from the skin and the further 
handling.

251 When a commercial test (SeptiFast) with a promising design was launched, the need for an evaluation was evident.

253 We thus chose to study an unselected group, aiming at including all adult patients seeking 254 medical attention at our department of infectious diseases, for whom a blood culture was 255 ordered during one full year.

257 In the present study there was no systematic loss of patients for inclusion. A loss was seen 258 however in a few situations of overload of the department, and as a result of some mistakes in 259 the sampling; also, a few single patients chose not to participate. Our handling of samples and 260 our laboratory work strictly followed the instructions from the manufacturer of SeptiFast. In 261 order not to create any bias, only one set of blood culture/PCR per patient was included for 262 evaluation.

263 With this approach we consider the patient material to be representative of a population that,

264 in most cases, reaches the hospital with an infection that they have developed outside the 265 healthcare systems, named community onset blood stream infection.

267 In the design of the SeptiFast test the ITS region has been selected as the target region. By

268 this approach a higher sensitivity can be achieved compared to single-copy genes, since there

269 are often several ribosomal operons in the genomes of bacteria and fungi $[9,11]$. A higher

270 specificity can also be obtained compared to rRNA, as the ITS is more species-specific.

271

272 The selected species of bacteria and fungi that can be identified by SeptiFast was calculated to 273 leave about $10 \%$ of our bacteraemias undiagnosed. Important pathogens are missing, such as 
274 the anaerobes, Salmonella, Shigella, Haemophilus species, and Neisseria meningitidis. In our 275 study 10 results (7\%) out of 146 positive BCs, from 138 patients, included pathogens not 276 covered by the SeptiFast.

277 In the evaluation, the results with the different diagnostic systems must also take into account 278 that the blood culture system uses 8-10 $\mathrm{ml}$ of venous blood per bottle (one aerobic and one 279 anaerobic bottle is taken in each culture), compared to the SeptiFast test which uses $1.5 \mathrm{ml}$ in 280 an EDTA tube with vacuum for preparation of a DNA extract for six PCR assays. One PCR 281 assay thus contains DNA from $0.25 \mathrm{ml}$ of blood or 1:32-40 of the blood culture volume used

282 in one bottle. This may have had implications for the diagnostic sensitivity.

284 In the SeptiFast assay high quality PCR reagents, free of bacterial or fungal DNA 285 contamination, are used according to the information provided by the producer. The EDTA 286 vacuum tubes for drawing venous blood were recommended by the producer and said to be 287 endotoxin and DNA free. The present study results, indicate, however that contamination was 288 a problem, giving false positive $E$. coli PCR results in some cases (8 out of 32 had no support 289 for the positive PCR result; Table 4) and P. aeruginosa in a few other cases (4 of 6 without 290 support; Table 4). Whether these contaminants came from the sampling tubes or the reagents

291 is not clear. Such problems have to be brought down to an absolute minimum by the 292 producers.

294 The background of a negative result with SeptiFast, despite positive BC with a bacterium that 295 is included in the test (false negative), is multifactorial. The reasons may be speculated on and 296 include possibly less optimal technical steps in the PCR reaction, incorrect interpretation of 297 amplification signals, problems with the selection of species-specific targets in the test, and 298 the blood volume used. 
In the present study the SeptiFast false negative S. pneumoniae bacteraemic cases are most

300 noteworthy, since only 2 of $16 \mathrm{BC}$ positive samples were detected, i.e. the sensitivity was

$30112 \%$. This may be explained by the fact that the manufacturer of SeptiFast has set the

302 detection level for S. pneumoniae high, in order not to have false-positive results caused by

303 closely related alpha-haemolytic streptococci. For optimal detection of S. pneumoniae DNA,

304 PCR targets specific to $S$. pneumoniae should probably be used. We recently found that PCR

305 for lytA applied to plasma samples had a sensitivity of $70 \%$ and a specificity of $99 \%$ for

306 detection of $S$. pneumoniae bacteraemia in patients with community-acquired pneumonia

307 [12].

308 The same problem was encountered for other bacteraemic streptococci, mainly beta-

309 haemolytic ones, which were negative in $57 \%$ in the SeptiFast test.

310 These results hamper the use of the tested version of SeptiFast for detection of bacteraemia in

311 a general infectious disease patient population, where pneumococci and invasive haemolytic

312 streptococci are common causes of community onset bacteraemia.

313

314 A positive result with SeptiFast when the BC is negative can be received in a number of 315 situations. Some of these results are clinically reliable and helpful and some are misleading.

316 A well defined contribution by the nucleic assay tests is the performance when antibiotics

317 have been given prior to culture, and individual patients in this situation were seen in the 318 present study (Table 2).

319 The presence of bacterial/fungal DNA in whole blood without live organisms has not so far

320 been systematically explored. Biologically it is a likely situation that could focus an

321 investigation on a search for a localised infection. The present study includes such patients,

322 for example with S. aureus positivity in SeptiFast (Table 4). 
323 Contamination of a blood sample as such in connection with the sampling of the patient

324 involves the skin flora from which mainly different staphylococci and streptococci become

325 positive in the diagnostic systems. The results for CoNS in the present study (Table 2)

326 indicate that there are problems with skin contamination. Both nucleic assay tests and culture

327 systems share these problems and results have to be repeated to be more reliable. A

328 semiquantitative view is also useful in these situations when a late and low PCR product and a

329 need for long-term incubation for growth favour the judgement of a contaminant $[13,14]$.

331 A number of studies, mainly with smaller study groups, using SeptiFast for the detection of

332 microbial DNAemia, have been published with various results. Several publications have

333 focused on compromised and highly selected patient groups, mainly from haematological

334 units $[15,16,17,18,19]$.

335 Some publications include community onset bloodstream infections. Louie et al studied 200

336 adult patients, sampled at emergency rooms, intensive care units and general medicine wards.

337 They found positive PCR in 45 cases compared to $37 \mathrm{BC}$, and $69 \%$ of the PCR results were

338 confirmed by blood, urine, and catheter culture [20]. Tsalik et al included 306 patients with

339 suspected sepsis. In the patients with an identified infectious aetiology, 66 were positive with

340 BC and 46 with PCR [21]. Avolio et al compared BC with SeptiFast in patients admitted to

341 the emergency room with suspected sepsis. Out of 144 samples, 30 identified the same

342 organism with BC and PCR, 13 organisms were identified only with BC, and 10 were positive

343 only with PCR [22]. West et al conducted a multicenter trial of patients with suspected

344 bacterial or fungal septicaemia. In total 359 patients were evaluated. The rate of positivity was

$34517 \%$ for BC and 26\% for SeptiFast. The 74 non-contaminant BC isolates were identified with

346 PCR in 50 cases. The 174 non-contaminant microorganisms detected by SeptiFast were

347 isolated by BC in 50 cases and additionally 67 could be confirmed as probable clinical 
348 pathogens by culture of the same microorganism from a relevant anatomical site within the

349 same clinical time frame. No support was found for a total of 57 samples [23].

350

351 In the present study, we found that the positivity rate of PCR was generally slightly lower

352 than that of BC. In agreement with the previous studies on the SeptiFast test, we found that

353 the test had high specificities and high negative predictive values for the detectable pathogens.

354 However, the sensitivities and PPVs of the test were suboptimal, facts that became obvious

355 with the layout of our study, with a large number of community onset consecutive patients.

356

357

358 Acknowledgements

359

360 The study was made possible by a research grant from the Research Committee of the County

361 Council of Örebro.

362

363 Reagents and means for technical assistance for the study were provided by Roche

364 Diagnostics.

365

366 There has been no other financial relationship with any other company.

367

368 Conflict of interest

369

370 The authors declare that they have no conflict of interest.

371 
372

373 1. Kumar A, Roberts D, Wood KE, Light B, Parrillo JE, Sharma S, Suppes R, Feinstein

374

375

376

377

378

379

380

381

382

383

384

385

386

387

388

389

390

391

392

393

\section{References}

\author{
D, Zanotti S, Taiberg L, Gurka D, Cheang M (2006) Duration of hypotension before
} initiation of effective antimicrobial therapy is the critical determinant of survival in human septic shock. Crit Care Med 34 (6):1589-1596

2. Beekmann SE, Diekema DJ, Chapin KC, Doern GV (2003) Effects of rapid detection of bloodstream infections on length of hospitalization and hospital charges. J Clin Microbiol 41 (7):3119-3125

3. Kollef MH, Sherman G, Ward S, Fraser VJ (1999) Inadequate antimicrobial treatment of infections: a risk factor for hospital mortality among critically ill patients. Chest $115(2): 462-474$

4. Ibrahim EH, Sherman G, Ward S, Fraser VJ, Kollef MH (2000) The influence of inadequate antimicrobial treatment of bloodstream infections on patient outcomes in the ICU setting. Chest 118 (1):146-155

5. Peters RP, van Agtmael MA, Danner SA, Savelkoul PH, Vandenbroucke-Grauls CM (2004) New developments in the diagnosis of bloodstream infections. Lancet Infect Dis 4 (12):751-760

6. Schrenzel J (2007) Clinical relevance of new diagnostic methods for bloodstream infections. Int J Antimicrob Agents 30 Suppl 1 S2-6

7. Mancini N, Carletti S, Ghidoli N, Cichero P, Burioni R, Clementi M (2010) The era of molecular and other non-culture-based methods in diagnosis of sepsis. Clin Microbiol $\operatorname{Rev} 23(1): 235-251$ 
394 8. Meier A, Persing DH, Finken M, Bottger EC (1993) Elimination of contaminating

395 DNA within polymerase chain reaction reagents: implications for a general approach

396 to detection of uncultured pathogens. J Clin Microbiol 31 (3):646-652

397 9. Lehmann LE, Hunfeld KP, Emrich T, Haberhausen G, Wissing H, Hoeft A, Stuber F 398 (2008) A multiplex real-time PCR assay for rapid detection and differentiation of 25 399 bacterial and fungal pathogens from whole blood samples. Med Microbiol Immunol $400 \quad 197(3): 313-324$

401 10. Murray PR, Baron EJ (2003) Manual of clinical microbiology. ASM Press, $402 \quad$ Washington, D.C.

403 11. Lau A, Chen S, Sorrell T, Carter D, Malik R, Martin P, Halliday C (2007)

404 Development and clinical application of a panfungal PCR assay to detect and identify 405 fungal DNA in tissue specimens. J Clin Microbiol 45 (2):380-385

406 12. Abdeldaim G, Herrmann B, Molling P, Holmberg H, Blomberg J, Olcen P, Stralin K 407 (2010) Usefulness of real-time PCR for lytA, ply, and Spn9802 on plasma samples for 408 the diagnosis of pneumococcal pneumonia. Clin Microbiol Infect 16 (8):1135-1141

409 13. Hall KK, Lyman JA (2006) Updated review of blood culture contamination. Clin $410 \quad$ Microbiol Rev 19 (4):788-802

411 14. Kassis C, Rangaraj G, Jiang Y, Hachem RY, Raad I (2009) Differentiating culture 412 samples representing coagulase-negative staphylococcal bacteremia from those 413 representing contamination by use of time-to-positivity and quantitative blood culture 414 methods. J Clin Microbiol 47 (10):3255-3260 
415 15. Mancini N, Clerici D, Diotti R, Perotti M, Ghidoli N, De Marco D, Pizzorno B,

416 Emrich T, Burioni R, Ciceri F, Clementi M (2008) Molecular diagnosis of sepsis in neutropenic patients with haematological malignancies. J Med Microbiol $57(\mathrm{Pt}$ 5):601-604

16. von Lilienfeld-Toal M, Lehmann LE, Raadts AD, Hahn-Ast C, Orlopp KS, Marklein G, Purr I, Cook G, Hoeft A, Glasmacher A, Stuber F (2009) Utility of a commercially available multiplex real-time PCR assay to detect bacterial and fungal pathogens in febrile neutropenia. J Clin Microbiol 47 (8):2405-2410

17. Varani S, Stanzani M, Paolucci M, Melchionda F, Castellani G, Nardi L, Landini MP, Baccarani M, Pession A, Sambri V (2009) Diagnosis of bloodstream infections in immunocompromised patients by real-time PCR. J Infect 58 (5):346-351

18. Casalta JP, Gouriet F, Roux V, Thuny F, Habib G, Raoult D (2008) Evaluation of the LightCycler(R) SeptiFast test in the rapid etiologic diagnostic of infectious endocarditis. Eur J Clin Microbiol Infect Dis 28 569-573

19. Lamoth F, Jaton K, Prod'hom G, Senn L, Bille J, Calandra T, Marchetti O (2010) Multiplex blood PCR in combination with blood cultures for improvement of microbiological documentation of infection in febrile neutropenia. J Clin Microbiol 48

20. Louie RF, Tang Z, Albertson TE, Cohen S, Tran NK, Kost GJ (2008) Multiplex (10):3510-3516

21. Tsalik EL, Jones D, Nicholson B, Waring L, Liesenfeld O, Park LP, Glickman SW, 437 Caram LB, Langley RJ, van Velkinburgh JC, Cairns CB, Rivers EP, Otero RM, 
22. Avolio M, Diamante P, Zamparo S, Modolo ML, Grosso S, Zigante P, Tosoni N, De Rosa R, Stano P, Camporese A (2010) Molecular identification of bloodstream pathogens in patients presenting to the emergency room with suspected sepsis. Shock $34(1): 27-30$

23. Westh H, Lisby G, Breysse F, Boddinghaus B, Chomarat M, Gant V, Goglio A, Raglio A, Schuster H, Stuber F, Wissing H, Hoeft A (2009) Multiplex real-time PCR and blood culture for identification of bloodstream pathogens in patients with suspected sepsis. Clin Microbiol Infect 15 (6):544-551 
462 Table 1: Bacteria and fungi detectable by the SeptiFast assay according to the manufacturer.

463

\begin{tabular}{lll}
\hline Gram-negative & Gram-positive & Fungi \\
\hline Escherichia coli & Staphylococcus aureus & Candida albicans \\
Klebsiella pneumoniae & Staphylococcus epidermidis & Candida tropicalis \\
Klebsiella oxytoca & Staphylococcus haemolyticus & Candida parapsilosis \\
Serratia marcescens & Streptococcus pneumoniae & Candida krusei \\
Enterobacter cloacae & Streptococcus pyogenes & Candida glabrata \\
Enterobacter aerogenes & Streptococcus agalactiae & Aspergillus fumigatus \\
Proteus mirabilis & Streptococcus mitis & \\
Pseudomonas aeruginosa & Enterococcus faecium & \\
Acinetobacter baumannii & Enterococcus faecalis & \\
Stenotrophomonas maltophilia & & \\
\hline
\end{tabular}

464

465

466

467

468

469

470

471

472

473

474

475

476

477

478

479

480

481

482

483

484 
485 Table 2: Pathogens detected by blood culture (BC) and/or PCR for species included in the 486 PCR test menu.

487

\begin{tabular}{|l|c|c|c|}
\hline & PCR + & PCR+ & PCR - \\
& BC + & BC - & BC + \\
& $\mathrm{n}^{\mathrm{a}}$ & $\mathrm{n}$ & $\mathrm{n}$ \\
\hline Pathogens & & & \\
\hline Coagulase-negative Staphylococcus (CoNS) & $1(0)$ & $10(2)$ & $30(8)$ \\
\hline Staphylococcus aureus & $10(2)$ & $13(4)$ & $5(0)$ \\
\hline Streptococcus pneumoniae & $2(0)$ & $1(1)$ & $14(0)$ \\
\hline Enterococcus faecalis & $3(1)$ & $0(0)$ & $2(0)$ \\
\hline other Streptococcus species & $10^{\mathrm{b}}(1)$ & $3(1)$ & $13^{\mathrm{c}}(0)$ \\
\hline Escherichia coli & $18(3)$ & $14(0)$ & $16(2)$ \\
\hline Enterobacter cloacae/aerogenes & $1(1)$ & $4(2)$ & $1(0)$ \\
\hline Klebsiella pneumoniae/oxytoca & $3(1)$ & $10(3)$ & $4(0)$ \\
\hline Serratia marcescens & $0(0)$ & $1(1)$ & $1(1)$ \\
\hline Pseudomonas aeruginosa & $1(0)$ & $5(1)$ & $0(0)$ \\
\hline Candida albicans & $1(1)$ & $1(0)$ & $0(0)$ \\
\hline Aspergillus fumigatus & $0(0)$ & $2(0)$ & $0(0)$ \\
\hline Total & $50(10)$ & $64(15)$ & $86(11)$ \\
\hline
\end{tabular}

${ }^{\mathrm{a}}$ Number with prior antibiotic treatment is shown in brackets.

${ }^{\mathrm{b}}$ Blood culture was positive for Streptococcus pyogenes $(\mathrm{n}=2)$, other $\beta$-haemolytic streptococci $(\mathrm{n}=4), \alpha$ haemolytic streptococci ( $\mathrm{n}=3)$, and Streptococcus bovis $(\mathrm{n}=1)$. haemolytic streptococci $(n=2)$. 
501 Table 3: Blood culture/PCR set with polymicrobial results $(n=12)$ : Positive results with $\geq 1$

502 method for more than one pathogen.

503

\begin{tabular}{|c|c|c|c|c|}
\hline $\begin{array}{l}\text { Sex, } \\
\text { Age }\end{array}$ & Diagnosis & PCR result & $\begin{array}{l}\text { Blood culture } \\
\text { aerobic bottle }\end{array}$ & $\begin{array}{c}\text { Blood culture } \\
\text { anaerobic bottle }\end{array}$ \\
\hline f,68 & Cholangitis & Escherichia coli & $\begin{array}{l}\text { E. coli, } \\
\text { Klebsiella species. }\end{array}$ & $\begin{array}{l}\text { E. coli, } \\
\text { Klebsiella species. }\end{array}$ \\
\hline $\mathrm{m}, 92$ & Cholangitis & $\begin{array}{l}\text { E. coli, } \\
\text { Klebsiella species. }^{\text {a }}\end{array}$ & E. coli & E. coli \\
\hline $\mathrm{m}, 80$ & Cholangitis & $\begin{array}{l}\text { E. coli, } \\
\text { Klebsiella species }\end{array}$ & neg & neg \\
\hline$f, 54$ & $\begin{array}{l}\text { Infection in central } \\
\text { venous access } \\
\text { device }\end{array}$ & $\begin{array}{l}\text { Enterococcus faecalis, } \\
\text { Enterobacter species. }\end{array}$ & $\begin{array}{l}\text { E. faecalis, } \\
\text { Enterobacter cloacae }\end{array}$ & E. faecalis, E. cloacae \\
\hline $\mathrm{f}, 80$ & $\begin{array}{l}\text { Urinary tract } \\
\text { infection }\end{array}$ & Staphylococcus aureus & neg & $\begin{array}{l}\text { Coagulase-negative } \\
\text { Staphylococcus (CoNS) }\end{array}$ \\
\hline$f, 64$ & $\begin{array}{l}\text { Urinary tract } \\
\text { infection }\end{array}$ & neg & $\begin{array}{l}\text { CoNS, } \\
\text { Aerococcus viridans }\end{array}$ & A. viridans \\
\hline $\mathrm{m}, 80$ & Erysipelas & neg & Group G streptococci & Group G streptococci, CoNS \\
\hline$f, 82$ & $\begin{array}{l}\text { Urinary tract } \\
\text { infection }\end{array}$ & $\begin{array}{l}\text { Pseudomonas } \\
\text { aeruginosa }\end{array}$ & P. aeruginosa & E. coli \\
\hline $\mathrm{m}, 87$ & $\begin{array}{l}\text { Urinary tract } \\
\text { infection }\end{array}$ & $\begin{array}{l}\text { S. aureus, } \\
\text { Candida albicans }\end{array}$ & S. aureus & S. aureus \\
\hline $\mathrm{m}, 88$ & \begin{tabular}{|l} 
Suspected \\
abdominal focus
\end{tabular} & $\begin{array}{l}\text { Streptococcus species, } \\
\text { Klebsiella species, } \\
\text { E. coli }\end{array}$ & $\begin{array}{l}\text { Streptococcus bovis, } \\
\text { Klebsiella species, } \\
\text { E. coli }\end{array}$ & $\begin{array}{l}\text { S. bovis, Klebsiella species, } \\
\text { E. coli }\end{array}$ \\
\hline $\mathrm{m}, 62$ & Diverticulitis & Streptococcus species. & neg & $\begin{array}{l}\text { Streptococcus anginosus, } \\
\text { Fusobacterium species. }\end{array}$ \\
\hline $\mathrm{m}, 48$ & Phlegmonous foot & $\begin{array}{l}\text { Streptococcus species, } \\
\text { P. aeruginosa }\end{array}$ & Streptococcus pyogenes & S. pyogenes \\
\hline 504 & \multicolumn{4}{|c|}{${ }^{\mathrm{a}}$ Klebsiella pneumoniae/oxytoca } \\
\hline 505 & ${ }^{\mathrm{b}}$ Enterobacter clo & zelaerogenes & & \\
\hline
\end{tabular}


507 Table 4: Positive SeptiFast results, results of other microbiological analyses, and possible

508 clinical support.

509

\begin{tabular}{|c|c|c|c|c|c|}
\hline \multirow[b]{2}{*}{ Species } & \multirow{2}{*}{$\begin{array}{c}\text { PCR } \\
+ \\
\\
\\
\mathrm{n}\end{array}$} & \multicolumn{2}{|c|}{ Microbiological support } & \multicolumn{2}{|c|}{$\begin{array}{c}\text { No microbiological } \\
\text { support }\end{array}$} \\
\hline & & $\begin{array}{c}\text { Full } \\
\text { support } \\
\text { by BC+ } \\
\text { (same } \\
\text { set) } \\
\text { n } \\
\end{array}$ & $\begin{array}{c}\text { Other } \\
\text { microbiological } \\
\text { support }^{\mathrm{a}} \\
\mathrm{n}\end{array}$ & $\begin{array}{c}\text { Clinical } \\
\text { support } \\
\mathrm{n}\end{array}$ & $\begin{array}{c}\text { No clinical } \\
\text { support } \\
n\end{array}$ \\
\hline Coagulase-negative Staphylococcus & 11 & 1 & 0 & 0 & 10 \\
\hline Staphylococcus aureus & 23 & 10 & 3 & 0 & 10 \\
\hline Streptococcus species & 13 & 10 & 2 & 0 & 1 \\
\hline Streptococcus pneumoniae & 3 & 2 & 0 & $1^{\mathrm{b}}$ & 0 \\
\hline Enterococcus faecalis & 3 & 3 & 0 & 0 & 0 \\
\hline Escherichia coli & 32 & 18 & 2 & $4^{\mathrm{c}}$ & 8 \\
\hline Enterobacter cloacae/aerogenes & 5 & 1 & 0 & 0 & 4 \\
\hline Klebsiella pneumoniae/oxytoca & 13 & 3 & 3 & $3^{d}$ & 4 \\
\hline Serratia marcescens & 1 & 0 & 0 & $1^{\mathrm{e}}$ & 0 \\
\hline Pseudomonas aeruginosa & 6 & 1 & 0 & $1^{\mathrm{f}}$ & 4 \\
\hline Candida albicans & 2 & 1 & 0 & 0 & 1 \\
\hline Aspergillus fumigatus & 2 & 0 & 0 & 0 & 2 \\
\hline Total & 114 & 50 & 10 & 10 & 44 \\
\hline
\end{tabular}

$510{ }^{a}$ Other microbiological support: Other blood cultures, cultures from normally sterile sites, bronchial secretions

511 and pure culture in urine and wounds. Wound culture with mixed flora including Staphylococcus aureus and $\beta$ -

512 haemolytic streptococci were also regarded as microbiological support.

$513{ }^{\mathrm{b}}$ Pneumonia.

$514{ }^{\mathrm{c}}$ Cholangitis $(\mathrm{n}=3)$ and cholecystitis $(\mathrm{n}=1)$.

$515{ }^{\mathrm{d}}$ Cholangitis $(\mathrm{n}=1)$ and urinary tract infection $(\mathrm{n}=2)$.

$516{ }^{\mathrm{e}}$ Relapsing cholangitis after liver transplantation.

$517{ }^{\mathrm{f}}$ Pneumonia after renal transplantation. 
520 Table 5: Sensitivities and positive predictive values including a combined reference standard

521 for major bacterial pathogens.

522

\begin{tabular}{|l|c|c|c|}
\hline \multirow{2}{*}{} & & \multicolumn{2}{|c|}{ Positive predictive value $^{\text {b }}$} \\
\cline { 3 - 4 } & & $\begin{array}{c}\text { Reference standard } \\
\text { Blood culture (BC) }\end{array}$ & $\begin{array}{c}\text { Reference standard } \\
\text { BC } \\
\text { and/or }\end{array}$ \\
\cline { 3 - 4 } & & & $\begin{array}{c}\text { Microbiological support } \\
\text { and/or }\end{array}$ \\
\hline Staphylococcus aureus & $67(10 / 15)$ & $43(10 / 23)$ & $\begin{array}{c}\text { Clinical support } \\
\text { Streptococcus pneumoniae }\end{array}$ \\
\hline other Streptococcus species & $12(2 / 16)$ & $67(2 / 3)$ & $100(3 / 3)$ \\
\hline Escherichia coli & $43(10 / 23)$ & $77(10 / 13)$ & $92(12 / 13)$ \\
\hline Klebsiella species & $53(18 / 34)$ & $56(18 / 32)$ & $75(24 / 32)$ \\
\hline
\end{tabular}

${ }^{\mathrm{a}}$ Data are \% (positive with PCR and BC/all positive with BC).

$523{ }^{\mathrm{b}}$ Data are \% (positive with PCR and reference standard/all positive with PCR). 